\title{
Modeling variations of marine reservoir ages during the last 45000 years
}

\author{
J. Franke ${ }^{1}$, A. Paul ${ }^{1,2}$, and M. Schulz ${ }^{1,2}$ \\ ${ }^{1}$ Department of Geosciences, University of Bremen, Germany \\ ${ }^{2}$ MARUM - Center for Marine Environmental Sciences, University of Bremen, Germany \\ Received: 7 December 2007 - Published in Clim. Past Discuss.: 25 January 2008 \\ Revised: 28 May 2008 - Accepted: 29 May 2008 - Published: 25 June 2008
}

\begin{abstract}
When dating marine samples with ${ }^{14} \mathrm{C}$, the reservoir-age effect is usually assumed to be constant, although atmospheric ${ }^{14} \mathrm{C}$ production rate and ocean circulation changes cause temporal and spatial reservoir-age variations. These lead to dating errors, which can limit the interpretation of cause and effect in paleoclimate data. We used a global ocean circulation model forced by transient atmospheric $\Delta^{14} \mathrm{C}$ variations to calculate reservoir ages for the last 45000 years for a present day-like and a last glacial maximum-like ocean circulation. A 30\% reduced Atlantic meridonal overturning circulation leads to increased reservoir ages by up to $\sim 500$ years in high latitudes. Temporal variations are proportional to the absolute value of the reservoir age; regions with large reservoir age also show large variation. Temporal variations range between $\sim 300$ years in parts of the subtropics and $\sim 1000$ years in the Southern Ocean. For tropical regions, which are generally assumed to have nearly stable reservoir ages, the model suggests variations of several hundred years.
\end{abstract}

\section{Introduction}

Late Quaternary sediments are frequently dated by means of their radiocarbon $\left({ }^{14} \mathrm{C}\right)$ content. ${ }^{14} \mathrm{C}$ originates in the atmosphere, where cosmic rays generate free neutrons that can react with nitrogen to produce ${ }^{14} \mathrm{C}$ (Masarik and Beer, 1999). After exchange with the other carbon reservoirs most of the radiocarbon is stored in the ocean, where it decays. The finite exchange flux between the reservoirs causes the radiocarbon age of marine sample always to be higher than that of a coeval atmospheric sample (Bard, 1988; Stuiver and Braziunas, 1993). This age difference is known as "reservoir age" and has to be taken into account in the conversion from radiocarbon age to calendar age.

Present-day (PD) reservoir ages average globally at about 400 years (Bard, 1988; Hughen et al., 2004a). Regional reservoir-age anomalies for the time before nuclear weapon tests are mainly known from sites along coastlines (Reimer and Reimer, 2001). Accordingly ${ }^{14} \mathrm{C}$ dates are mostly corrected for a local but constant PD reservoir age instead of the global mean. Temporal reservoir-age variations in contrast are hardly considered when marine samples are dated, because they could only be scarcely reconstructed for limited time periods and at a few locations (Southon et al., 1990; Bard et al., 1994; Austin et al., 1995; Burr et al., 1998; Sikes et al., 2000; Siani et al., 2001; Waelbroeck et al., 2001; Keigwin and Schlegel, 2002; Kovanen and Easterbrook, 2002; Eiriksson et al., 2004; Bard and Rostek, 2005; Fairbanks et al., 2005; Bondevik et al., 2006; Schimmelmann et al., 2006; Hughen et al., 2006). These reconstructions suggest that reservoir-age changes of several hundred years occurred in the late Quaternary. Errors of such a magnitude might lead to a misinterpretations of cause and effect in paleoclimate time series.

Changes in the geomagnetic field, which directly influences the atmospheric ${ }^{14} \mathrm{C}$ production rate are considered to be the main reason for reservoir-age variations (Laj et al., 1996). Model experiments suggest that the strength Atlantic meridional overturning circulation (AMOC) also significantly influences atmospheric $\Delta^{14} \mathrm{C}\left(\Delta^{14} \mathrm{C}_{\mathrm{atm}}\right)$ and subsequently reservoir ages, too (Delaygue et al., 2003; Muscheler et al., 2004). Running a spatially explicit ocean circulation model forced by changes in atmospheric ${ }^{14} \mathrm{C}$ offers the opportunity to assess a major part of reservoirs age variability, that is induced by ${ }^{14} \mathrm{C}$ production rate changes. 

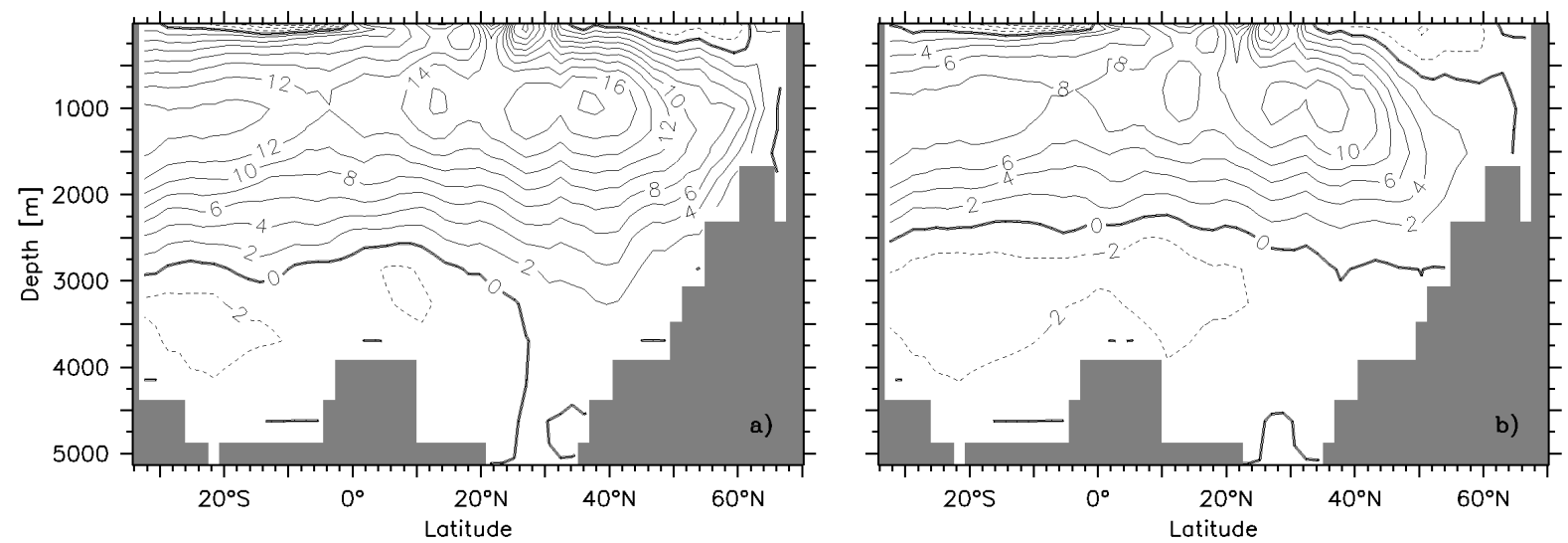

Fig. 1. (a) Atlantic Ocean meridional streamfunction $[\mathrm{Sv}]$ of the model simulation with PD forcing and in (b) with LGM forcing. With LGM-like boundary conditions the AMOC is reduced by approximately one third and shallower such that AABW can reach further north at the bottom of the ocean.

\section{Model setup}

The reservoir-age calculation was done using a global model of intermediate complexity, the University of Victoria Earth System Climate Model (UVic ESCM) in version 2.7 (Weaver et al., 2001). It consists of a three-dimensional ocean general circulation model (Modular Ocean Model, version 2, Pacanowski (1995)), coupled to a two-dimensional energymoisture balance model of the atmosphere (Fanning and Weaver, 1996) and a dynamic-thermodynamic sea-ice model (Bitz et al., 2001). The horizontal resolution of all components is $3.6^{\circ}$ in longitude and $1.8^{\circ}$ in latitude. The ocean has 19 levels of irregular depth, increasing from $50 \mathrm{~m}$ at the surface to $500 \mathrm{~m}$ at the deepest levels (Weaver et al., 2001). It is driven by variations in solar insolation over a year at the top of the atmosphere. The wind stress at the ocean surface is prescribed from a monthly climatology (Kalnay et al., 1996). We used the option of a rotated grid to avoid convergence of the meridians towards the North Pole. Sub-gridscale mixing is included following the Gent and McWilliams (1990) parametrization for mixing associated with mesoscale eddies. Vertical diffusion is increasing from $0.3 \mathrm{~cm}^{2} \mathrm{~s}^{-1}$ in the thermocline to $1.3 \mathrm{~cm}^{2} \mathrm{~s}^{-1}$ in the deep ocean (Bryan and Lewis, 1979).

To evaluate if the model simulates PD ocean circulation right, a control experiment was set up, using PD parameters as a solar radiation and land-ice distribution of the year 1950 Common Era (CE), monthly mean winds from reanalysis data of the 20th century (Kalnay et al., 1996) and a preindustrial atmospheric $\mathrm{CO}_{2}$ content of $280 \mathrm{ppmv}$. In this configuration the model shows a maximum North Atlantic overturning of $20 \mathrm{~Sv}$ and a southward export of North Atlantic Deep Water (NADW) at $30^{\circ} \mathrm{S}$ of $14 \mathrm{~Sv}$ (Fig. 1a). Antartic Bottom Water (AABW) reaches up to $30^{\circ} \mathrm{N}$. All these values agree fairly well with calculations based on observational data (Talley et al., 2003). Finally a circumpolar current of around $100 \mathrm{~Sv}$ is comparable with observations compiled by Orsi et al. (1995).

In the ocean part of the model, radiocarbon was included as a passive tracer following the guidelines of the Ocean Carbon Modeling Intercomparison Project (OCMIP-2, Orr et al., 2000):

$F_{\text {air-sea }}=K_{w}\left({ }^{14} \mathrm{C}_{\text {sat }}-{ }^{14} \mathrm{C}_{\text {surf }}\right)$

with

${ }^{14} \mathrm{C}_{\mathrm{sat}}=\alpha \mathrm{C} \cdot p \mathrm{CO}_{2} \cdot\left(P / P_{0}\right) \cdot R_{\mathrm{std}}$

$K_{w}=\left(1-f_{\text {ice }}\right)\left(a \cdot u^{2}\right)(\mathrm{Sc} / 660)^{\frac{1}{2}}$,

and

$\mathrm{Sc}=2073.1-125.62 \cdot \mathrm{SST}+3.63 \cdot \mathrm{SST}^{2}-0.043 \cdot S S T^{3}$

where $F_{\text {air-sea }}$ is the flux of ${ }^{14} \mathrm{C}$ from the atmosphere to the ocean, $K_{w}$ is $\mathrm{CO}_{2}$ gas transfer velocity, ${ }^{14} \mathrm{C}_{\text {sat }}$ and ${ }^{14} \mathrm{C}_{\text {surf }}$ are the ${ }^{14} \mathrm{C}$ concentrations in the atmosphere and surface ocean respectively, $\alpha \mathrm{C}$ is the carbon solubility for water-vapor saturated air $\left[\frac{\mathrm{mol}}{\mathrm{m}^{3} \cdot \mu \mathrm{atm}}\right], p \mathrm{CO}_{2}$ is partial pressure of $\mathrm{CO}_{2}$ in the atmosphere, $P$ is local sea level air pressure, $P_{0}$ is the mean sea-level air pressure of $1013.25 \mathrm{hPa}, R_{\text {std }}$ is the normalized ratio of $\frac{{ }^{14} \mathrm{C}}{{ }^{12} \mathrm{C}}, f_{\text {ice }}$ is the modeled fraction of sea-ice coverage (height $>1 \mathrm{~cm}$ ), $a$ is a constant to adjust the global flux, $u^{2}$ is windspeed in $\left[\frac{\mathrm{m}}{\mathrm{s}}\right]$ and $\mathrm{Sc}$ is sea-surface temperature (SST $[\mathrm{K}]$ ) dependend Schmidt number.

The gas exchange with the atmosphere depends on the atmosphere to surface-ocean ${ }^{14} \mathrm{C}$ gradient, windspeed, sea-ice cover and sea-surface temperature. In the ocean the radiocarbon tracer is transported via diffusion and advection like all the other tracer (e.g. temperature, salinity). A sink has 
been added to account for the radiocarbon decay with the true half-life of 5730 years.

The atmosphere is treated as one well-mixed box with respect to ${ }^{14} \mathrm{C}$ because the atmospheric mixing time for ${ }^{14} \mathrm{C}$ is on the order of some years, which is much shorter than the timescale of interest. Splitting the atmosphere into troposphere and stratosphere is not necessary, because this would only have an influence on variations at timescales shorter than 20 years (Siegenthaler et al., 1980). The terrestrial biosphere has an effect if forcing variations are on timescales from a few decades to some centuries (Siegenthaler et al., 1980). As we concentrated on even longer variations, the terrestrial biosphere is also not taken into account, to make the model more efficient.

\section{Experiments and model forcing}

\subsection{Control run and model evaluation}

In the control experiment $\Delta^{14} \mathrm{C}_{\mathrm{atm}}$ is held constant at $0 \%$, which is defined as the pre-industrial ${ }^{14} \mathrm{C} /{ }^{12} \mathrm{C}$-ratio of the year $1850 \mathrm{CE}$. To evaluate the model, we compared the oceanic ${ }^{14} \mathrm{C}$ distribution with the global carbon climatology (Key et al., 2004). This dataset includes the radiocarbon measurements at the time of sampling as well as calculated estimates for natural background and bomb-produced ${ }^{14} \mathrm{C}$. The gas exchange of the model was reduced by $\sim 20 \%$ compared to OCMIP recommendations (Orr et al., 2000), which is in agreement with recent calculations (Sweeney et al., 2007).

\section{2 $\Delta^{14} \mathrm{C}$ variations in a bomb ${ }^{14} \mathrm{C}$ experiment}

Since our main interest is to simulate temporal reservoirsage variations, the model response to ${ }^{14} \mathrm{C}$ production rate changes needs to be verified. This can be achieved in an experiment, which is forced by the well-known radiocarbon production due to the test of nuclear weapons during the second half of the 20th century. Estimates for the nuclear bomb strength were taken from Hesshaimer et al. (1994). The model was started from the the Suess-effect corrected PD equilibrium state described in the last section and was run for 40 years. $\Delta^{14} \mathrm{C}$ measurements used for comparison are in the atmosphere spatially weighted global means based on regional data of Hua and Barbetti (2004) and in the ocean shallow-water coral data (Druffel, 1989).

\subsection{Influence of different ocean circulation states}

To study the influence of different ocean circulation states on the ${ }^{14} \mathrm{C}$ distribution, the model was forced by LGM-like boundary conditions: Insolation and land ice distribution were set to $21 \mathrm{kyr} \mathrm{BP}$ and the atmospheric $\mathrm{CO}_{2}$ concentration was reduced to $200 \mathrm{ppmv}$ (Table 1). Using these parameters the Atlantic Meridional Overturning Circulation (AMOC)
Table 1. Forcing of different reservoir-age simulations.

\begin{tabular}{lcc}
\hline & PD & LGM \\
\hline Insolation & $1950 \mathrm{CE}$ & $21 \mathrm{kyr} \mathrm{BP}$ \\
Land ice & $1950 \mathrm{CE}$ & $21 \mathrm{kyr} \mathrm{BP}$ \\
& & ${\mathrm{ICE}-5 \mathrm{G}^{\mathrm{a}}}$ \\
$\mathrm{CO}_{2}$ & $280 \mathrm{ppmv}$ & $200 \mathrm{ppmv}$ \\
Windfields & recent NCEP/NCAR & recent NCEP/NCAR \\
& Reanalysis $^{\mathrm{b}}$ & Reanalysis $^{\mathrm{b}}$ \\
\hline
\end{tabular}

a Peltier (2004)

b Kalnay et al. (1996)

became weaker by roughly one third and it became shallower, such that AABW could penetrate further northward in the deep Atlantic (Fig. 1). This weaker and shallower overturning cell is consistent with the glacial nutrient distribution, $\mathrm{Pa} / \mathrm{Th}$ and most other circulation tracers (Schmittner et al., 2002; Meissner et al., 2003; McManus et al., 2004; LynchStieglitz et al., 2007). Reconstructions of dust and pollen transport (e.g. Stuut et al., 2002; Shi et al., 2001) as well as climate models (e.g. Braconnot et al., 2007) suggest an increased wind speed during the last glacial maximum. In the UVic ESCM a higher wind speed leads to an intensification of NADW formation because the model cannot resolve the increased sea-ice/fresh-water transport with the East Greenland and Labrador Current to the North Atlantic that can be observed in models of higher spatial resolution such as the Community Climate System Model (CCSM) in the PMIP-2 project (Braconnot et al., 2007). To assess the influence of a reduced circulation which is in agreement with most reconstructions on the reservoir ages the PD wind fields are also used for the LGM simulations following Meissner et al. (2003).

\subsection{Atmospheric $\Delta^{14} \mathrm{C}$ forcing}

To study past changes in oceanic ${ }^{14} \mathrm{C}$ content, we prescribed the temporal $\Delta^{14} \mathrm{C}$ evolution based on reconstructions. For this we used the INTCAL04 dataset (Reimer et al., 2004) up to $25 \mathrm{kyr}$ BP. Between 25 and $50 \mathrm{kyr}$ BP we used the reconstructions by Fairbanks et al. (2005) and Hughen et al. (2006) because they could remove some of the uncertainties that caused disagreement in earlier reconstructions (e.g. Voelker et al., 1998; Bard et al., 1998; Goslar et al., 2000; Kitagawa and Plicht, 2000; Beck et al., 2001; Hughen et al., 2004b). Remaining uncertainties in the reconstructions such as the assumption of a constant low latitude reservoir age to estimate $\Delta^{14} \mathrm{C}_{\mathrm{atm}}$ from marine reconstructions between 12.4 and $50 \mathrm{kyr}$ BP are discussed in Sect. 5.1. The $\Delta^{14} \mathrm{C}_{\mathrm{atm}}$ model-forcing dataset was constructed by interpolating an error weighted spline (Williams and Kelley, 2007) through the selected reconstructions which leads to a slightly smoothed ${ }^{14} \mathrm{C}$ production rate (Fig. 2). 


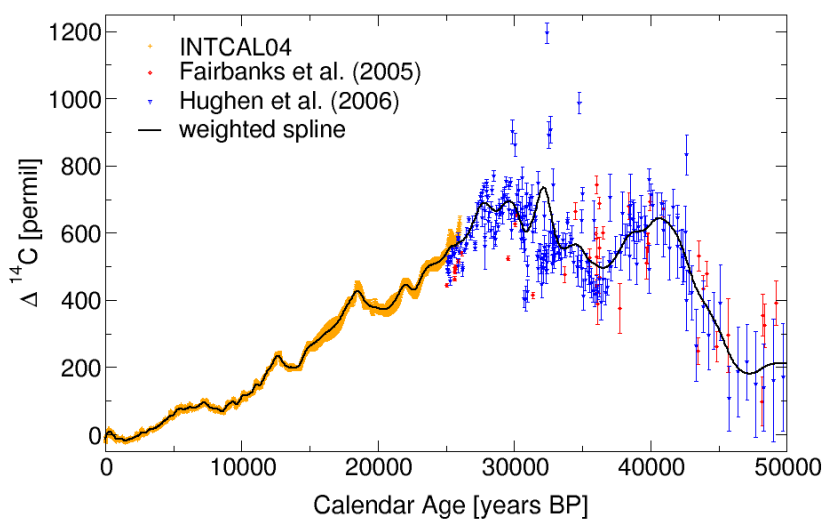

Fig. 2. INTCAL04 $\Delta{ }^{14} \mathrm{C}_{\text {atm }}$ and its $1 \cdot \sigma$ error estimate (Reimer et al., 2004, orange), coral data (Fairbanks et al., 2005, red) and Cariaco Basin sediment data (Hughen et al., 2006, blue). A spline function (black) was interpolated through the data weighted by the $1 \cdot \sigma$ error of all the reconstructed values.

The long time period needed to reach an equilibrium between atmospheric and oceanic ${ }^{14} \mathrm{C}$ concentrations requires a model spin-up time of several thousand years (Siegenthaler et al., 1980). As only very few $\Delta{ }^{14} C_{\text {atm }}$ reconstructions exist prior to $50 \mathrm{kyr}$ BP (Hughen et al., 2006; van Kreveld et al., 2000; Voelker et al., 2000), we spun up the model from $75 \mathrm{kyr} B \mathrm{P}$ using a ${ }^{14} \mathrm{C}$ production rate, calculated after (after Masarik and Beer, 1999) from a global paleomagnetic intensity stack (GLOPIS, Laj et al., 2004). At $50 \mathrm{kyr}$ BP the forcing was switched to the interpolated $\Delta^{14} \mathrm{C}$ spline. This change of forcings adds some uncertainty to the initial oceanic ${ }^{14} \mathrm{C}$ level, beside the possibility of a different ocean circulation state.

\section{Results}

\subsection{Control run and bomb experiment}

The modeled $\Delta^{14} \mathrm{C}$ distribution agrees with the pre-nuclear GLobal Ocean Data Analysis Project (GLODAP, Key et al., 2004) estimate mostly within $\pm 10 \%$ (Fig. 3). Only in upwelling areas and in the deep northern Pacific Ocean the model predicts too negative $\Delta^{14} \mathrm{C}$ values (up to $30 \%$ difference). This is the result of too strong tropical upwelling, which is a prevalent feature of most coarse resolution ocean models with high vertical diffusivity (Toggweiler et al., 1989; Orr, 2002). In the equilibrium experiment the global mean surface ocean $\Delta^{14} \mathrm{C}$ is $-61 \%$ o close to the bomb ${ }^{14} \mathrm{C}$ corrected GLODAP estimate of $-65 \%$. Therewith, the UVic ESCM is able to simulate the oceanic $\Delta^{14} \mathrm{C}$ distribution more accurately than most OCMIP-2 models, many of which have problems simulating NADW reaching depths below $3000 \mathrm{~m}$ and which showed $\Delta^{14} \mathrm{C}$ deviations in comparison with mea- surements up to $\pm 50 \%$ over large regions of the deep northern Pacific and deviations ranging from +80 to $-40 \%$ in the Southern Ocean (Orr, 2002).

Forced by the ${ }^{14} \mathrm{C}$ production rate changes due to nuclear weapon testing, the model is able to predict temporal $\Delta{ }^{14} \mathrm{C}_{\mathrm{atm}}$ variations in good agreement with observations (Fig. 4).

The uptake of bomb radiocarbon by the ocean can be analyzed by comparing the model's temporal response with a time series of reconstructed surface-ocean $\Delta^{14} \mathrm{C}$ based on corals (Druffel, 1989). Near Bermuda the model slightly underestimates the $\Delta^{14} \mathrm{C}$ measured in corals (Fig. 5. One reason could be that the UVic ESCM is too diffusive. Thus, the radiocarbon is transported into the subsurface ocean faster than in reality. An alternative explanation is that the wellstratified region, where the corals were actually sampled, is not resolved by the too coarse resolution of the model or that this region is the spatially shifted by a few degrees. This is supported by the fact that at a location $10^{\circ}$ south and $4^{\circ}$ east the observed $\Delta^{14} \mathrm{C}$ is also predicted by the model (Fig. 5).

\subsection{Time slices}

We ran two simulations for the different circulation states of the ocean, both with the same time-dependent $\Delta{ }^{14} C_{a t m}$ forcing. Three time slices of this simulation are plotted in Fig. 6. One for the "Laschamp" event $41 \mathrm{kyr} \mathrm{BP}$, which is important in relationship to the radiocarbon history because the geomagnetic field collapsed almost completely, resulting in a high ${ }^{14} \mathrm{C}$ production (Laj et al., 2000). The LGM was chosen as a second time slice because of its paleoclimatic importance, and finally PD for comparison.

The PD reservoir ages, reached at the end of the transient experiment for a modern ocean circulation (Fig. 6a), are slightly smaller than in the equilibrium experiment because $\Delta^{14} \mathrm{C}_{\mathrm{atm}}$ had a decreasing trend over the last centuries before this snapshot was taken. Nevertheless the reservoir-age estimates agree with present day observation of 400-500 years in the northern North Atlantic, 300-400 years in the subtropical oceans and up to 1000 years close to Antarctica. For an AMOC reduced by $\sim 30 \%$, the model suggests larger reservoir ages than with a modern circulation, reaching values of 400-1400 years (Fig. 6b).

The LGM falls in a time period of decreasing $\Delta{ }^{14} \mathrm{C}_{\mathrm{atm}}$. If the circulation would have been like today the model predicts reservoir ages to be below present day values, ranging from 200 years in the subtropical ocean up to 900 years close to Antarctica (Fig. 6c). The reduced AMOC leads to increased reservoir ages reaching from 300 to 1200 years (Fig. 6d).

During the Laschamp event and its high ${ }^{14} \mathrm{C}$ production rate the model suggests globally increased reservoir ages of $400-1400$ years if the circulation would have been like today (Fig. 6e) and of 500-1800 years in case of the reduced AMOC (Fig. 6f). 

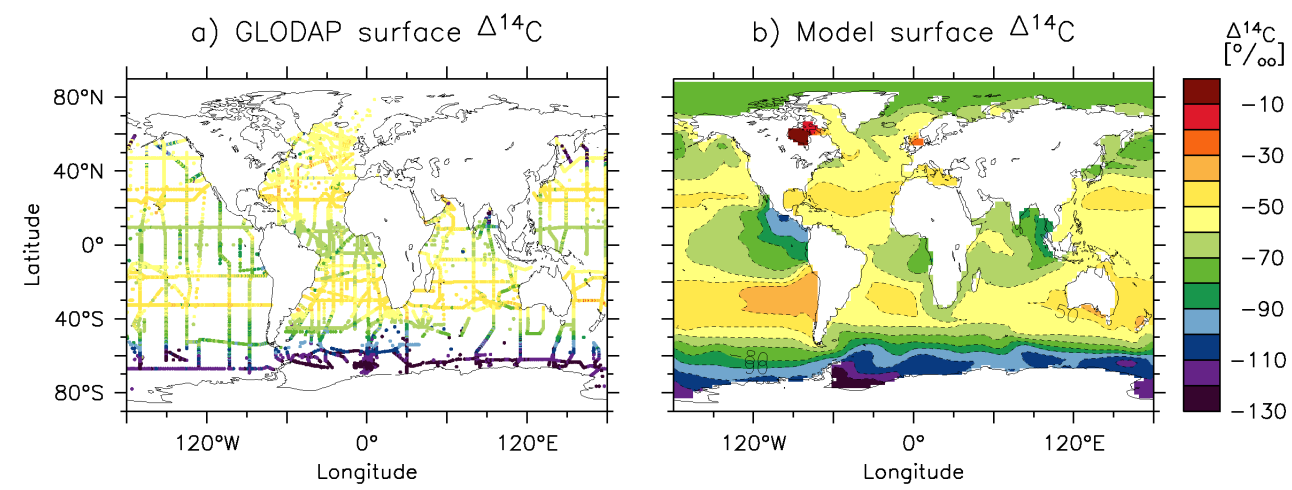

c) GLODAP zonal mean AtI. $\triangle^{14} \mathrm{C}$

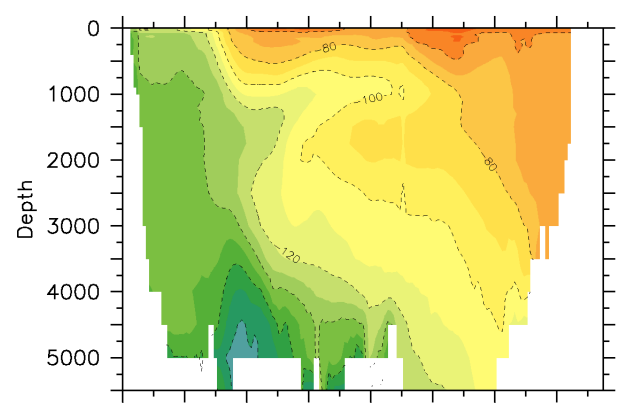

d) Modeled zonal mean Atl. $\triangle^{14} \mathrm{C}$

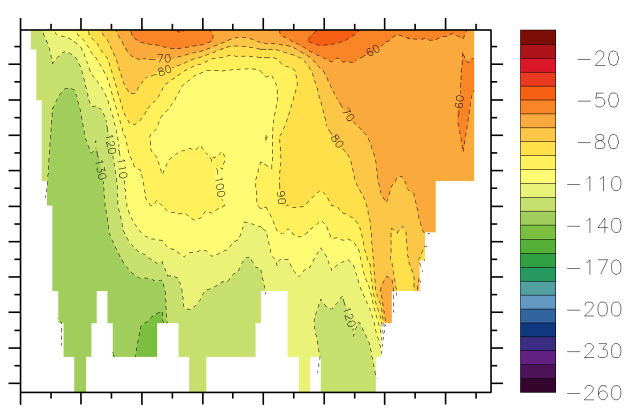

e) GLODAP zonal mean Pac. $\triangle^{14} \mathrm{C}$

f) Modeled zonal mean Pac. $\Delta^{14} \mathrm{C}$
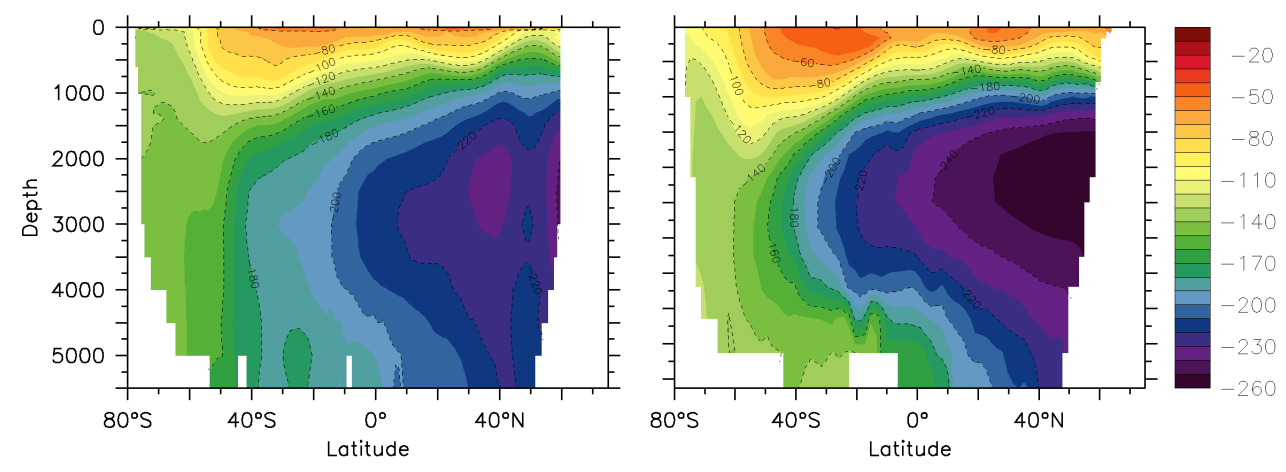

Fig. 3. Model/data comparison: (a) Surface ocean background $\Delta^{14} \mathrm{C}$ (measured value minus calculated bomb fraction) from the GLODAP carbon data compilation (Key et al., 2004). (b) Surface ocean $\Delta^{14} \mathrm{C}$ in the UVic ESCM PD control run with constant $\Delta{ }^{14} \mathrm{C}=0 \%$ o. (c) Interpolated zonal mean Atlantic $\Delta^{14} \mathrm{C}$ depth profile from the GLODAP dataset; (d) modeled Atlantic; (e) GLODAP zonal mean profile for the Pacific and (f) the modeled Pacific.

\subsection{Temporal reservoir-age variations}

The amplitude of the modeled temporal reservoir-age variations over the last $45 \mathrm{kyr}$ varies spatially. This is shown for the simulation with PD boundary conditions (Fig. 7). The amplitude of temporal variations with LGM boundary conditions are very similar, only shifted to higher reservoir-ages. The smallest changes occur in some subtropical regions but even there the range of temporal variation is rarely below 300 years. In the northern North Atlantic these variation are larger and reach up to 700 years. Largest reservoir-age varia- tions were modeled for the Southern Ocean where they could exceed 1000 years. Reservoir-age increases coincide with $\Delta^{14} \mathrm{C}_{\mathrm{atm}}$ increases and the other way around.

\subsection{Reduced Atlantic meridional overturning circulation}

To analyze the influence of circulation changes induced reservoir-age differences separated from the temporal $\Delta^{14} \mathrm{C}_{\mathrm{atm}}$ variations, the control experiment with the PD circulation is compared with an experiment of constant $\Delta{ }^{14} \mathrm{C}_{\mathrm{atm}}$ and LGM-like boundary conditions. In the LGM- 


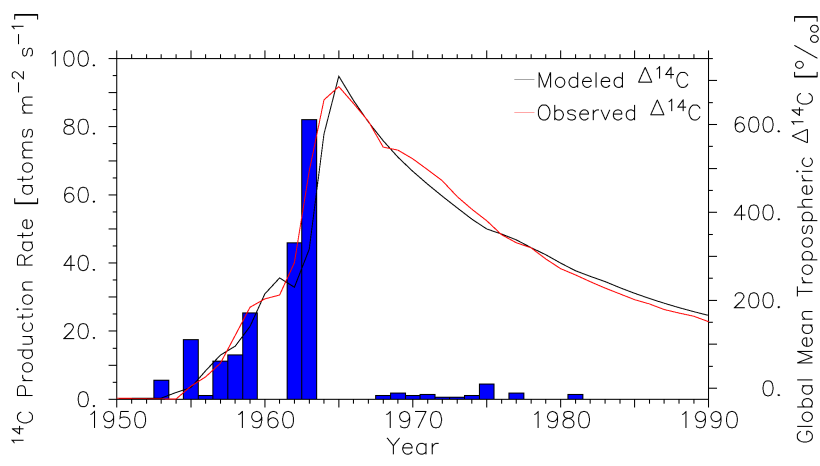

Fig. 4. Observed and modeled $\Delta{ }^{14} \mathrm{C}_{\mathrm{atm}}$ due to nuclear weapon tests. The blue bars represent the ${ }^{14} \mathrm{C}$ production which was caused by nuclear weapon tests (Hesshaimer et al., 1994). The red curve shows the observed and globally averaged $\Delta^{14} \mathrm{C}_{\mathrm{atm}}$ (Hua and Barbetti, 2004), while the black curve is the response of the model to the production rate forcing.

like simulation $\Delta^{14} \mathrm{C}_{\mathrm{atm}}$ was set to zero instead of the reconstructed LGM value to allow for a direct comparison of the results.

In an equilibrium state, reservoir ages increase globally with the LGM forcing (Fig. 8). The circulation induced differences stay small at around 100-200 years in the subtropical and tropical regions with strong stratification and slow diffusive mixing of deep water into the surface. Largest anomalies of 250-400 years could be seen in the Southern Ocean and even up to 500 years in the Arctic Ocean, probably a result of increased sea-ice coverage that limits the gas exchange.

\section{Discussion}

\subsection{Atmospheric ${ }^{14} \mathrm{C}$ forcing}

In principal there exist two possibilities to model atmospheric ${ }^{14} \mathrm{C}$ variations. One approach would be the forcing of the model with a ${ }^{14} \mathrm{C}$ production rate, the other option is $\Delta{ }^{14} \mathrm{C}_{\mathrm{atm}}$ reconstructions. The ${ }^{14} \mathrm{C}$ production rate variations can be calculated based on reconstructions of geomagnetic intensity (e.g. Valet et al., 2005; Laj et al., 2004) or ${ }^{10} \mathrm{Be}$ (Muscheler et al., 2004) using the method of Masarik and Beer (1999).

So far, no model has been able to reproduce the reconstructed $\Delta{ }^{14} \mathrm{C}$ values of far above $500 \%$ in the atmosphere during the last glacial, using ${ }^{14} \mathrm{C}$ production rates alone (Beck et al., 2001; Laj et al., 2000, 2002; Hughen et al., 2004b; Muscheler et al., 2004). More complex models showed even lower $\Delta^{14} \mathrm{C}$ values in the atmosphere than simple models as it could be seen in the difference between a 17box and a 4-box model (Laj et al., 2002). Forced with the ${ }^{14} \mathrm{C}$ production rate, based on the global paleointensity stack (Laj et al., 2004), the UVic ESCM confirms the results of the box

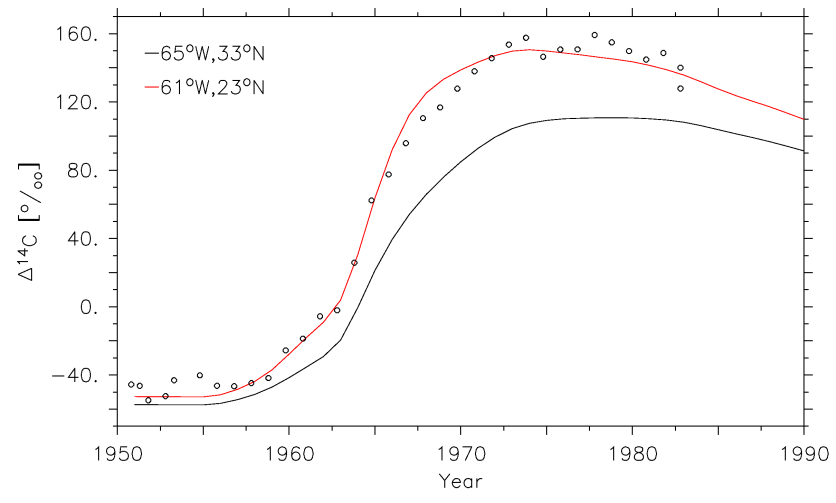

Fig. 5. Modeled and reconstructed $\Delta^{14} \mathrm{C}$ close to Bermuda $\left(33^{\circ} \mathrm{N}\right.$, $\left.65^{\circ} \mathrm{W}\right)$. The black circles represent shallow-water coral measurements (Druffel, 1989), the black curves is modeled $\Delta^{14} \mathrm{C}$ at the same location and the red curve is the model output at the ocean surface at $23^{\circ} \mathrm{N}, 61^{\circ} \mathrm{W}$.

models used in other studies before and only simulates up to $\sim 300 \%$ o (Supplementary Material: http://www.clim-past. net/4/125/2008/cp-4-125-2008-supplement.pdf). To reach the observed $\Delta{ }^{14} C_{\text {atm }}$ values, which are approximately twice as large, major changes in the carbon cycle are required. One possible explanation would be a glacial deep-ocean carbon reservoir that is well isolated from the atmosphere and stores radiocarbon depleted waters (Marchitto et al., 2007).

Generally the absolute $\Delta{ }^{14} \mathrm{C}_{\mathrm{atm}}$ value is irrelevant for the reservoir age, as it can be seen in Fig. 7, in which glacial reservoir ages vary around the same level as ages in the Holocene, although $\Delta^{14} \mathrm{C}_{\mathrm{atm}}$ was a few hundred permil higher. Instead, the rate of $\Delta^{14} C_{\text {atm }}$ change is the essential factor. Hence, modeled reservoir age variation do not have to differ in magnitude between the ${ }^{14} \mathrm{C}$ production rate and the $\Delta^{14} \mathrm{C}_{\mathrm{atm}}$ forcing, as long as production-rate increase and AMOC reduction do not occur at the same time. Still major reservoir age changes would stay unconsidered because the production rate can only explain half of the overall variability.

The $\Delta{ }^{14} \mathrm{C}$ forcing has the advantage that the variations, which were not caused by atmospheric ${ }^{14} \mathrm{C}$ production rate changes also appear in the simulated reservoir ages. Measurement uncertainties in the ${ }^{14} \mathrm{C}$ reconstructions could be reduced, so the large scatter between different datasets decreased over the last years. Nevertheless the reconstructions before $12.4 \mathrm{kyr}$ BP still do not agree with each other completely (Fairbanks et al., 2005; Hughen et al., 2006), e.g. because the calibration to an age scale is often associated with some uncertainties or because an unknown reservoir age has to be assumed for marine samples. To convert the marine $\Delta^{14} \mathrm{C}$ values from corals and sediments to an atmospheric value, constant reservoir ages have been applied, as no reservoir-age variation estimates exist for the low latitudes in the last glacial or the deglaciation. 

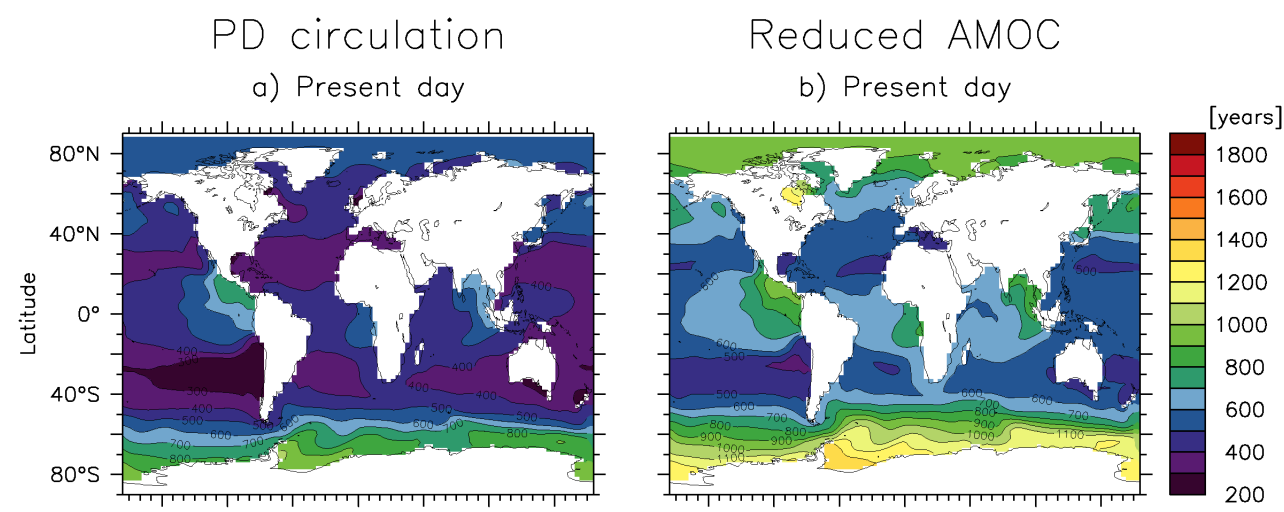

c) 21,000 years $\mathrm{BP}$

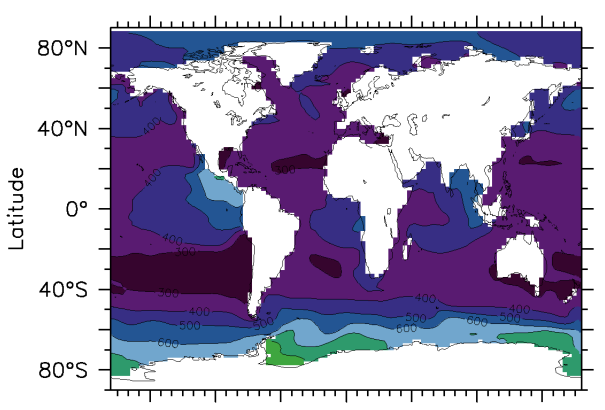

e) 41,000 years

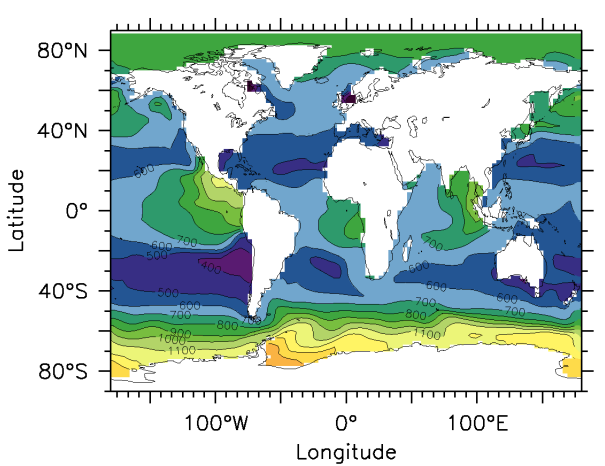

d) 21,000 years $\mathrm{BP}$

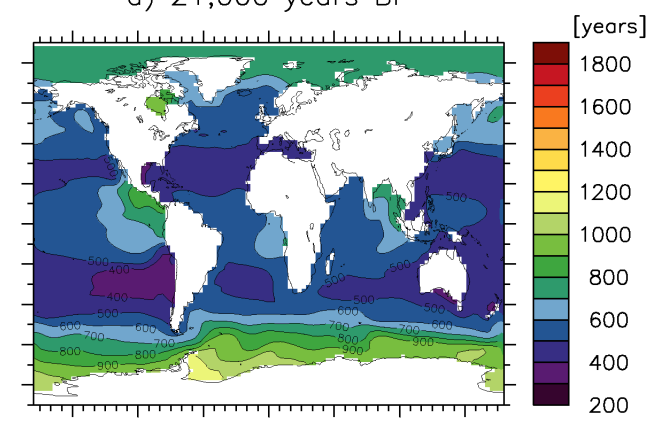

f) 41,000 years

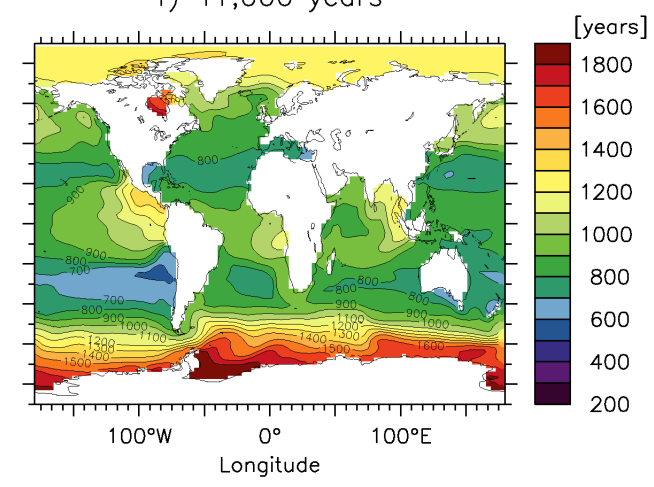

Fig. 6. Modeled reservoir ages for selected time slices, for PD (a and b), the LGM $21 \mathrm{kyr}$ BP (c and d) and for the "Laschamp" event $41 \mathrm{kyr} \mathrm{BP}$ (e and $\mathbf{f}$ ), when the geomagnetic field broke down nearly completely, resulting in a high ${ }^{14} \mathrm{C}$ production. The figures a, $\mathrm{c}$ and e on the left hand site were generated from the simulation with PD forcing, (b), (d) and (f) on the right hand site with the reduced AMOC under LGM boundary conditions.

If we assume reservoir-age variation in (sub)tropics, a temporally increased reservoir age implies that the reconstructed $\Delta^{14} \mathrm{C}_{\mathrm{atm}}$ is underestimated compared to the value calculated with a constant reservoir age. If the real reservoir age is smaller than the constant one, $\Delta^{14} \mathrm{C}_{\mathrm{atm}}$ is overestimated. This together might cause modeled reservoir-age variations to be underestimated because reservoir-age increases coincide with $\Delta^{14} \mathrm{C}$ increases and the other way around (see Sect. 4.3).
Based on the bomb experiment we think that the $\Delta^{14} \mathrm{C}_{\mathrm{atm}}$ forcing can be treated as the ${ }^{14} \mathrm{C}$ production rate forcing in the model. Simulating long-term variations, there will always be enough time for the ocean to equilibrate with the atmosphere within the gas exchange rate limitations.

The disadvantage of the $\Delta^{14} \mathrm{C}_{\text {atm }}$ forcing is that any $\Delta^{14} \mathrm{C}_{\mathrm{atm}}$ increase acts as if it was caused by a production rate increase. This may lead to artefacts in deep water formation areas during times of reduced deep water production, since the coupling of the surface layer to the deep ocean remains 

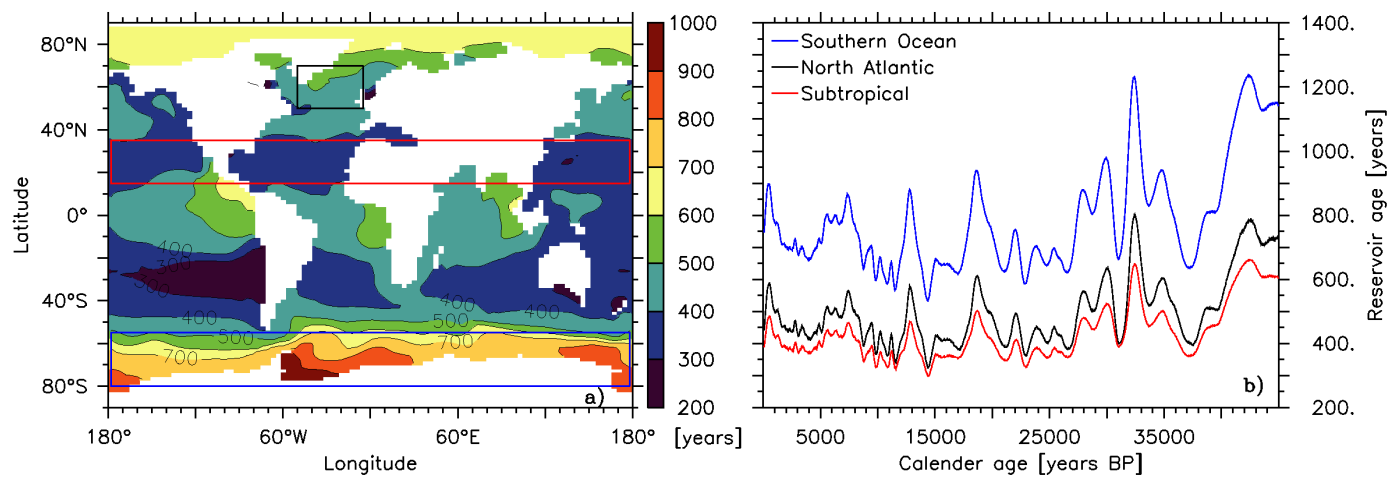

Fig. 7. Modeled range of reservoir-age variations over the time period from $45 \mathrm{kyr}$ BP to PD in (a). In (b) the regional mean reservoir-age variations are plotted for the areas indicated by equally colored rectangles in (a).

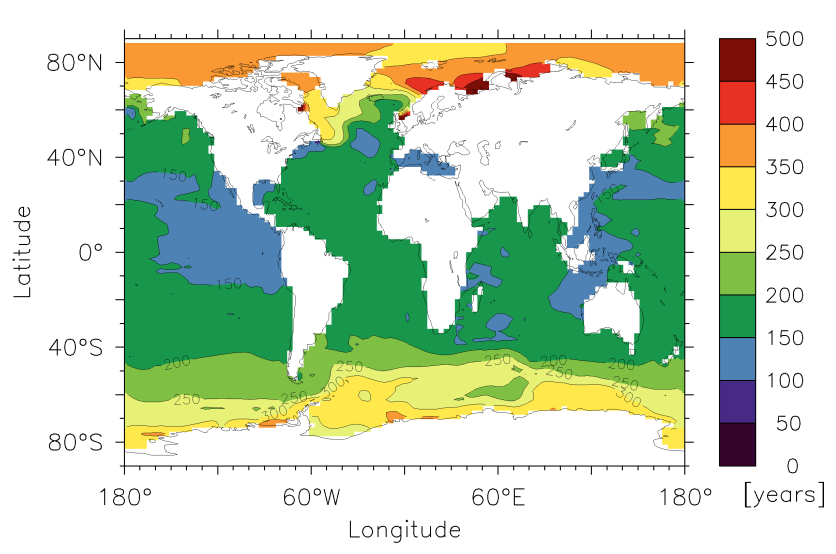

Fig. 8. Anomaly map of the equilibrium reservoir age modeled with reduced AMOC minus reservoir age simulated with present day AMOC.

unchanged. In these cases our modeled reservoir-age variations will be slightly underestimated again.

\subsection{Reservoir-age variations}

The comparably large oceanic carbon reservoir responds to atmospheric $\Delta^{14} \mathrm{C}$ changes with a time lag due to limited gas exchange. A $\Delta{ }^{14} \mathrm{C}_{\text {atm }}$ increase leads to a larger atmosphereocean ${ }^{14} \mathrm{C}$ difference and accordingly to a reservoir age increase, because the ocean cannot react fast enough, e.g. around $41 \mathrm{kyr} \mathrm{BP}$ (Fig. 7). As soon as $\Delta^{14} \mathrm{C}_{\mathrm{atm}}$ stops rising or is reduced, the reservoir ages decrease again. The opposite is true when $\Delta{ }^{14} \mathrm{C}_{\mathrm{atm}}$ declines, e.g. around $15 \mathrm{kyr} \mathrm{BP}$.

Changes in reservoir ages occur globally nearly simultaneously because the fast varying and well mixed atmosphere is the key driver (Fig. 7). In contrast, the amplitude of the reservoir-age variations differs at any location. Regions of large reservoir ages are as well as areas of large reservoir-age variations, like the Southern Ocean with more than 1000 years of PD surface ${ }^{14} \mathrm{C}$ age and also variations of more than 1000 years (Fig. 6 and 7). In a period of a $\Delta{ }^{14} C_{a t m}$ increase the radiocarbon content of the atmosphere increases while radiocarbon depleted water wells up from the deep ocean, which was once at the sea surface, when atmospheric $\Delta{ }^{14} \mathrm{C}$ was much lower. This causes the ${ }^{14} \mathrm{C}$ gradient between atmosphere and ocean to be larger than caused by the limited gas exchange alone. In the opposite case of a $\Delta{ }^{14} \mathrm{C}_{\mathrm{atm}}$ decrease, upwelling water was in contact with an atmosphere of higher $\Delta^{14} \mathrm{C}$ which leads to smaller reservoir ages.

In case of reservoir age changes that are not caused by ${ }^{14} \mathrm{C}$ production rate variation, the simulated reservoir age change is correct, but not the level, at which the reservoir ages remain after that first change. Box models suggested that more deep water production will transport more radiocarbon into the deep ocean and finally decreases atmospheric $\Delta^{14} \mathrm{C}$. In contrast, a reduced AMOC will lead to a lower ${ }^{14} \mathrm{C}$ transport into the deep ocean and to increased atmospheric $\Delta^{14} \mathrm{C}$ (Beck et al., 2001; Laj et al., 2002; Hughen et al., 2004b). The observed global reservoir-age increase in our simulation with a reduced AMOC agrees with this finding (Fig. 8). Temporally stable reservoir-age shifts can be initiated by changes in the carbon reservoirs. A $\Delta{ }^{14} \mathrm{C}_{\mathrm{atm}}$ increase in the model forcing, increases the atmosphere-ocean ${ }^{14} \mathrm{C}$ difference in the first moment as well, but because of the constant deep water formation, the ocean starts to take up more ${ }^{14} \mathrm{C}$, too. This decreases the reservoir ages again in the model, while they would remain larger in reality as long as the carbon reservoirs stay in a different state, like in the simulation with LGM boundary conditions.

Reservoir ages of 700-800 years were reconstructed in the northern North Atlantic (Bard et al., 1994; Sarnthein et al., 2001; Waelbroeck et al., 2001) and even 2000 years close to New Zealand (Sikes et al., 2000). Further evidence for large reservoir-age variations comes from ${ }^{14} \mathrm{C}$-plateau matching, 
which suggest North Atlantic reservoir ages of 2000 years and more during Heinrich event 1 (Sarnthein et al., 2007). If we add up the modeled temporal variations of up to 1000 years, variations subsequent to the reduced AMOC of up to 500 years or even more in case of a complete deepwater formation shutdown and including the underestimated effects mentioned in section 5.1, reservoir-ages variations of above 2000 years, appear to be reasonable in some regions. From the model simulation we would expect such large variations only in the Southern Ocean but not in the northern North Atlantic.

Modeled reservoir-age variation are not limited to high latitudes, they reach up to a few hundred years in tropical oceans, which were believed to be nearly stable (Hughen et al., 2004a). This has implications for the dating of atmospheric samples, because it adds some uncertainty to all ${ }^{14} \mathrm{C}$ calibration curves, which assume a constant reservoir age prior to $12.4 \mathrm{kyr} \mathrm{BP}$.

\subsection{Potential of modeled reservoir ages}

In constrast to reservoir-age reconstructions, estimates from an ocean circulation model are available at every location, time and also at different depth levels. The depth is important factor because reconstructions are often based on foraminifera that calcified between sea surface and $250 \mathrm{~m}$ depth (Simstich et al., 2003; Schiebel and Hemleben, 2005). The reservoir age of a species living in $250 \mathrm{~m}$ depth can severly differ from the surface reservoir age. This occurs especially in the North Pacific where reservoir ages in $250 \mathrm{~m}$ depth are up to 500 years larger than at the ocean surface. Model results suggest that it is also important to consider the living depth of a species before correcting for the reservoir age in other regions.

Nevertheless the modeled reservoir ages should not be directly applied to correct marine ${ }^{14} \mathrm{C}$ ages because only two constant ocean circulation states have been studied and because the UVic ESCM is not able to resolve all circulation features on a regional scale accurately. Thus, the model results indicate the possible reservoir-age variability for the specific region and time period of interest. The reliability of the model at the site and differences to the simulated ocean circulation need to be interpreted, before the modeled reservoir ages can be used for the ${ }^{14} \mathrm{C}$ age correction or to assess the error in the apparent age that is caused by reservoir-age variations.

\subsection{Comparison of modeled and reconstructed reservoir ages for the Younger Dryas}

Finally the reliability of modeled reservoir ages should be checked by a comparison with reconstructions. For this purpose the North Atlantic is the best covered region. For the time period from the Bølling to the Preboreal reservoir ages were reconstructed from co-existing marine and terrestrial

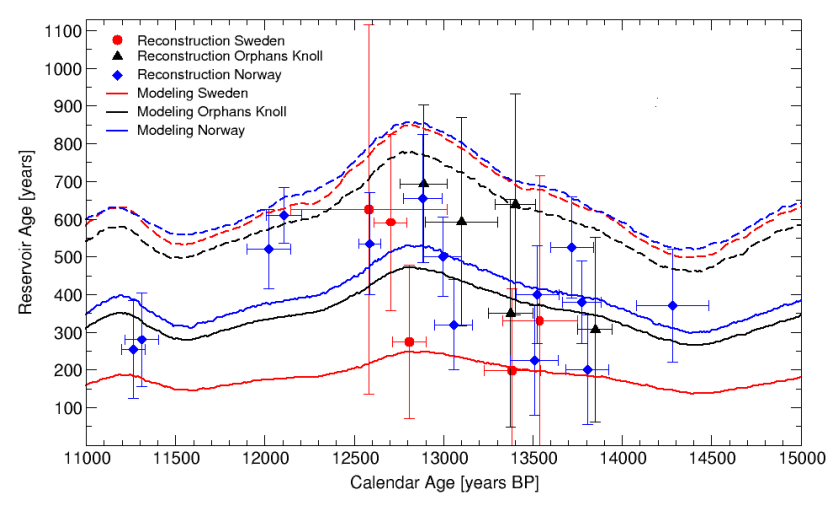

Fig. 9. Reconstructed and modeled reservoir ages from the Bølling/Allerød over the Younger Dryas to the Preboreal: The symbols represent the reconstructed reservoir ages for three regions in the northern North Atlantic, Sweden (Björck et al., 1998), Norway (Bondevik et al., 1999, 2006) and Orphans Knoll (Cao et al., 2007). The modeled mean reservoir ages at the sample locations are plotted for the PD circulation (straight curve) and for the reduced AMOC simulation (dashed curve).

material (Björck et al., 1998; Bondevik et al., 1999, 2006), from volcanic ash layers (Bard et al., 1994; Austin et al., 1995) and from corals (Cao et al., 2007). The presented reconstructions of Bondevik et al. (2006) and Cao et al. (2007) are based on the tree-ring ${ }^{14} \mathrm{C}$ series of Kromer et al. (2004). It should be noted that a new positioning of the tree-ring data has recently been suggested (Muscheler et al., 2008) which would decrease the reconstructed reservoir ages in the early Younger Dryas.

The reconstructions show large scatter and have large error bars, which nearly cover the whole range of variations, e.g. reservoir ages from Norway at nearly the same time between 13.7 and $13.8 \mathrm{kyr}$ BP show $\sim 400$ years difference (Fig. 9). Nevertheless there is a trend from PD-like reservoir ages around 400 years in the Bølling, over an increase in the Allerød to the Younger Dryas reservoir ages of circa 600 years and finally a decrease towards a PD value in the Preboreal again. The model predicts the $\mathrm{B} \emptyset$ lling reservoir age, the increase in the Allerød and the PD-like values in the Preboreal very well in the run with the PD circulation. Only during the Younger Dryas ( 12.9-11.6 kyr BP) the modeled reservoir ages remain below the reconstructed values and they start to decrease too quickly after reaching a maximum at the beginning of the Younger Dryas. It is thought that the cause of this reservoir age increase was a slowdown of the AMOC during the Younger Dryas (e.g. McManus et al., 2004). In the model simulation with reduced AMOC, the predictions for Younger Dryas reach or even exceed the reconstructions. The fact that reservoir-ages decrease too early with the PD forcing demonstrates that a ${ }^{14} \mathrm{C}_{\mathrm{atm}}$ model forcing changes reservoir ages temporally like an atmospheric ${ }^{14} \mathrm{C}$ production rate variations, but it can only generate the initial peak of an carbon reservoir change induced reservoirage variation. The correct interpretation and consideration of 
ocean circulation changes is therefore essential, when simulated reservoir ages should be applied for an age correction of marine samples.

A compilation of reconstructions from different location might create the wrong impression that reservoir ages should be the same everywhere. Indeed, the existence of local differences can hardly be seen in the scatter of the data but simulation results clearly show a $\sim 50$ year reservoir-age difference between Norway and Orphans Knoll (Fig. 9). The modeled reservoir ages for Sweden differ largely between the simulated AMOC states. That highlights that a reduction of the AMOC always increases the reservoir ages but by spatially different amounts.

The comparison of modeling results and reconstructions shows that our model can simulate the reservoir-age variation induced by changes in $\Delta^{14} \mathrm{C}_{\mathrm{atm}}$ in the correct order of magnitude. It is difficult to determine the quality of the model results due to the large scatter in the reconstructions.

\section{Conclusions}

Our ocean general circulation model confirms the results of previous box-model experiments that geomagnetic variations alone appear to be insufficient to explain reconstructed atmospheric ${ }^{14} \mathrm{C}$ variations in the last glacial and the deglaciation.

Simulations of past reservoir-age variations, using a $\Delta{ }^{14} C_{a t m}$ forcing, emphasize the need to make a temporal, spatial and depth depended reservoir-age correction when marine samples are dated with the radiocarbon method. The model suggests reservoir-age variations of several hundred years within some centuries due to ${ }^{14} \mathrm{C}$ production rate and ocean circulation changes. The modeled reservoir-age variations are not limited to high latitudes and can reach up to a few hundred years in tropical oceans. This has implications for ${ }^{14} \mathrm{C}$ calibration curves, which are mainly based on coral data and a constant reservoir age.

For regions and time periods, where no reservoir-age variation can be reconstructed, the model results can indicate potential reservoir-age variations. Modeled reservoir ages are available online (www.reservoirage.uni-bremen.de).

Acknowledgements. This work was funded by the Deutsche Forschungsgemeinschaft (DFG). We greatly appreciate Michael Eby's support in model related questions and Andreas Manschke's assistance in setting up the webserver. Finally we would like to thank the three anonymous reviewers for their constructive suggestions.

Edited by: G. M. Ganssen

\section{References}

Austin, W. E. N., Bard, E., Hunt, J. B., Krooni, D., and Peacock, J. D.: The ${ }^{14} \mathrm{C}$ age of the Icelandic Vedde ash: Implications for Younger Dryas marine reservoir age corrections, Radiocarbon, 37, 53-62, 1995.
Bard, E.: Correction of accelerator mass spectrometry ${ }^{14} \mathrm{C}$ ages measured in planktonic foraminifera: paleoceanographic implications, Paleoceanography, 3, 635-645, 1988.

Bard, E., Arnold, M., Mangerud, J., Paterne, M., Labeyrie, L., Duprat, J., Mélières, M.-A., Sønstegaard, E., and Duplessy, J.-C.: The North Atlantic atmosphere-sea surface ${ }^{14} \mathrm{C}$ gradient during the Younger Dryas climatic event, Earth Planet. Sci. Lett., 126, 275-287, 1994.

Bard, E., Arnold, M., Hamelin, B., Tisneratlaborde, N., and Caboich, G.: Radiocarbon calibration by means of mass spectrometric ${ }^{230} \mathrm{Th} /{ }^{234} \mathrm{U}$ and ${ }^{14} \mathrm{C}$ ages of corals: An updated database including samples from Barbados, Mururoa and Tahiti, Radiocarbon, 40, 1085-1092, 1998.

Bard, E., Ménot-Combes, G., and Rostek, F.: Present status of radiocarbon calibration and comparison records based on Polynesian corals and Iberian margin sediments, Radiocarbon, 46, 1189-1202, 2005.

Beck, J. W., Richards, D. A., Edwards, L., Silverman, B. W., Smart, P. L., Donahue, D. J., Hererra-Osterheld, S., Burr, G. S., Calsoyas, L., Jull, A. J. T., and Biddulph, D.: Extremly Large Variations of Atmospheric ${ }^{14} \mathrm{C}$ Concentration During the Last Glacial Period, Science, 292, 2453-2458, 2001.

Bitz, C. M., Holland, M. M., Weaver, A. J., and Eby, M.: Simulating the ice-thickness distribution in a coupled climate model, J. Geophys. Res., 106, 2441-2464, 2001.

Björck, S., Bennike, O., Possnert, G., Wohlfahrt, B., and Digerfeldt, G.: A high-resolution ${ }^{14} \mathrm{C}$ dated sediment sequence from southwest Sweden: age comparisons between different components of the sediment, J. Quaternary Sci., 13, 85-89, 1998.

Bondevik, S., Birks, H. H., Gulliksen, S., and Mangerud, J.: Late Weichselian Marine ${ }^{14} \mathrm{C}$ Reservoir Ages at the Western Coast of Norway, Quaternary Res., 52, 104-114, 1999.

Bondevik, S., Mangerud, J., Birks, H. H., Gulliksen, S., and Reimer, P.: Changes in North Atlantic Radiocarbon Reservoir Ages During the Allerød and Younger Dryas, Science, 312, 1514-1517, 2006.

Braconnot, P., Otto-Bliesner, B., Harrison, S., Joussaume, S., Peterschmitt, J.-Y., Abe-Ouchi, A., Crucifix, M., Driesschaert, E., Fichefet, T., Hewitt, C. D., Kageyama, M., Kitoh, A., Lainé, A., Loutre, M.-F., Marti, O., Merkel, U., Ramstein, G., Valdes, P., Weber, S. L., Yu, Y., and Zhao, Y.: Results of PMIP2 coupled simulations of the Mid-Holocene and Last Glacial Maximum Part 1: experiments and large-scale features, Clim. Past, 3, 261277, 2007, http://www.clim-past.net/3/261/2007/.

Bryan, K. and Lewis, L. J.: A water mass model of the world ocean circulation, J. Geophys. Res., C84, 2503-2517, 1979.

Burr, G. S., Beck, J. W., Taylor, F. W., Recy, J., Edwards, L., Cabioch, G., Correge, T., Donahue, D. J., and O'Malley, J. M.: A high-resolution radiocarbon calibration between 11,700 and 12,400 calendar years BP derived from ${ }^{230}$ Th ages of corals from Esperitu Santo Island, Vanuatu, Radiocarbon, 40, 1093-1151, 1998.

Cao, L., Fairbanks, R. G., Mortlock, R. A., and Risk, M. J.: Radiocarbon reservoir age of high latitude North Atlantic surface water during the last deglacial, Quaternary Sci. Rev., 26, 732742, 2007.

Delaygue, G., Stocker, T. F., Joos, F., and Plattner, G.-K.: Simulation of atmospheric radiocarbon during abrupt oceanic circu- 
lation changes: trying to reconcile models and reconstructions, Quaternary Sci. Rev., 22, 1647-1658, 2003.

Druffel, E.: Decade time scale variability of ventilation in the North Atlantic: High-precision measurements of bomb radiocarbon in banded corals, J. Geophys. Res., C94, 3271-3285, 1989.

Eiriksson, J., Larsen, G., Knudsen, K. L., Heinemeier, J., and Simonarson, L. A.: Marine reservoir age variability and water mass distribution in the Iceland Sea, Quaternary Sci. Rev., 23, 22472268, 2004.

Fairbanks, R. G., Mortlock, R. A., Chiu, T.-C., Cao, L., Kaplan, A., Guilderson, T. P., Fairbanks, T. W., Bloom, A. L., Grootes, P. M., and Nadeau, M.-J.: Radiocarbon calibration curve spanning 0 to 50,000 years BP based on paired ${ }^{230} \mathrm{Th} /{ }^{234} \mathrm{U} /{ }^{238} \mathrm{U}$ and ${ }^{14} \mathrm{C}$ dates on pristine corals, Quaternary Sci. Rev., 24, 1781-1796, 2005.

Fanning, A. F. and Weaver, A. J.: An atmospheric energy-moisture balance model: climatology, interpentadal climate change, and coupeling to an ocean general circulation model, J. Geophys. Res., D101, 15 111-15 128, 1996.

Gent, P. R. and McWilliams, J. C.: Isopycnal mixing in ocean circulation models, J. Phys. Oceanogr., 20, 150-155, 1990.

Goslar, T., Arnold, M., Tisnerat-Laborde, N., Czernik, J., and Wieckowski, K.: Variations of Younger Dryas atmospheric radiocarbon explicable without ocean circulation changes, Nature, 405, 877-880, 2000.

Hesshaimer, V., Heimann, M., and Levin, I.: Radiocarbon evidence for a smaller oceanic carbon dioxide sink than previously believed, Nature, 370, 201-203, 1994.

Hua, C. and Barbetti, M.: Review of tropospheric bomb ${ }^{14} \mathrm{C}$ data for carbon cycle modeling and age calibration purposes, Radiocarbon, 46, 1273-1298, 2004.

Hughen, K. A., Baillie, M. G. L., Bard, E., Beck, J. W., Bertrand, C. J. H., Blackwell, P. G., Buck, C. E., Burr, G. S., Cutler, K. B., Damon, P. E., Edwards, R. L., Fairbanks, R. G., Friedrich, M., Guilderson, T. P., Kromer, B., McCormac, G., Manning, S., Ramsey, C. B., Reimer, P. J., Reimer, R. W., Remmele, S., Southon, J. R., Stuiver, M., Talamo, S., Taylor, F. W., Plicht, J. v. d., and Weyhenmeyer, C. E.: MARINE04 Marine Radiocarbon Age Calibration, 0-26 cal kyr BP, Radiocarbon, 46, 1059-1086, 2004a.

Hughen, K. A., Lehman, S., Southon, J., Overpeck, J., Marchal, O., Herring, C., and Turnbull, J.: ${ }^{14} \mathrm{C}$ Activity and Global Carbon Cycle Changes over the Past 50,000 Years, Science, 303, 202207, 2004b.

Hughen, K. A., Lehman, S., Southon, J., Overpeck, J., Marchal, O., Herring, C., and Turnbull, J.: Marine-derived ${ }^{14} \mathrm{C}$ calibration and activity record for the past 50,000 years updated from the Cariaco Basin, Quaternary Sci. Rev., 25, 3216-3227, 2006.

Kalnay, E., Kanamitsu, M., Kistler, R., Collins, W., Deaven, D., Gandin, L., Iredell, M., Saha, S., White, G., Woollen, J., Zhua, Y., Leetmaa, A., Reynolds, B., Chelliah, M., Ebisuzaki, W., Higgins, W., Janowiak, J., Mo, K. C., Ropelewski, C., Wang, J., Jenne, R., and Joseph, D.: The NCEP/NCAR 40-year reanalysis project, B. Am. Meteorol. Soc., 77, 437-471, 1996.

Keigwin, L. D. and Schlegel, M. A.: Ocean ventilation and sedimentation since the glacial maximum at $3 \mathrm{~km}$ in the western North Atlantic, Geochemistry, Geophysics, Geosystems, 3, 114, 2002.

Key, R. M., Kozyr, A., Sabine, C. L., Lee, K., Wanninkhof, R.,
Bullister, J. L., Feely, R. A., Millero, F. J., Mordy, C., and Peng, T.-H.: A global ocean carbon climatology: Results from Global Data Analysis Project (GLODAP), Global Biogeochem. Cy., 18, 1-23, 2004.

Kitagawa, H. and Plicht, J. v. d.: Atmospheric radiocarbon calibration beyond 11,900 cal BP from Lake Suigetsu laminated sediments, Radiocarbon, 42, 369-380, 2000.

Kovanen, D. and Easterbrook, D.: Paleodeviations of radiocarbon marine reservoir values for the NE Pacific, Geology, 30, 243 246, 2002.

Kromer, B., Friedrich, M., Hughen, K. A., Kaiser, F., Remmele, S., Schaub, M., and Talamo, S.: Late Glacial ${ }^{14} \mathrm{C}$ ages from a oating 1382-ring pine chronology, Radiocarbon, 46, 1203-1209, 2004.

Laj, C., Mazaud, A., and Duplessy, J.-C.: Geomagnetic intensity and ${ }^{14} \mathrm{C}$ abundance in the atmosphere and ocean during the past 50kyr, Geophys. Res. Lett., 23, 2045-2048, 1996.

Laj, C., Kissel, C., Mazaud, A., Channell, J. E. T., and Beer, J.: North Atlantic paleointensity stack since $75 \mathrm{ka}$ (NAPIS-75) and the duration of the Laschamp event, Philosophical Transactions Royal Society, 358, 1009-1025, 2000.

Laj, C., Kissel, C., Mazaud, A., Michel, E., Muscheler, R., and Beer, J.: Geomagnetic field intensity, North Atlantic Deep Water circulation and atmospheric ${ }^{14} \mathrm{C}$ during the last $50 \mathrm{kyr}$, Earth Planet. Sci. Lett., 200, 177-190, 2002.

Laj, C., Kissel, C., and Beer, J.: high Resolution Global Paleointensity Stack Since $75 \mathrm{kyr}$ (GLOPIS-75) Calibrated to Absolute Values, Geophysical Monograph Series, 145, 255-265, 2004.

Lynch-Stieglitz, J., Adkins, J. F., Curry, W. B., Dokken, T., Hall, I. R., Herguera, J. C., Hirschi, J. J.-M., Ivanova, E. V., Kissel, C., Marchal, O., Marchitto, T. M., McCave, I. N., McManus, J. F., Mulitza, S., Ninnemann, U., Peeters, F., Yu, E.-F., and Zahn, R.: Circulation During the Last Glacial Maximum, Science, 316 , 66-69, 2007.

Marchitto, T. M., Lehman, S.J. Ortiz, J. D., Flückiger, J., and Geen, A. v.: Marine Radiocarbon Evidence for the Mechanism of Deglacial Atmospheric $\mathrm{CO}_{2}$ Rise, Science, 316, 1456-1459, 2007.

Masarik, J. and Beer, J.: Simulations of particle fluxes and cosmogenic nuclide production in the earth's atmosphere, J. Geophys. Res., D104, 12 099-13 012, 1999.

McManus, J. F., Francois, R., Gherardi, J.-M., Keigwin, L. D., and Brown-Leger, S.: Collapse and rapid resumption of Atlantic meridional circulation linked to deglacial climate changes, Nature, 428, 834-837, 2004.

Meissner, K. J., Schmittner, A., Weaver, A. J., and Adkins, J. F.: Ventilation of the North Atlantic Ocean during the Last Glacial Maximum: A comparison between simulated and observed radiocarbon ages, Paleoceanography, 18, 1023, 2003.

Muscheler, R., Beer, J., Gerhard Wagner, G., Carlo Laj, C., Kissel, C., Raisbeck, G. M., Yiou, F., and Kubik, P. W.: Changes in the carbon cycle during the last deglaciation as indicated by the comparison of ${ }^{10} \mathrm{Be}$ and ${ }^{14} \mathrm{C}$ records, Earth Planet. Sci. Lett., 219, 325-340, 2004.

Muscheler, R., Kromer, B., Bjorck, S., Svensson, A., Friedrich, M., Kaiser, K. F., and Southon, J.: Tree rings and ice cores reveal ${ }^{14} \mathrm{C}$ calibration uncertainties during the Younger Dryas, Nature Geoscience, 1, 218-219, 2008.

Orr, J.: Global Ocean Storage of Anthropogenic Carbon (GOSAC), Tech. rep., IPSL/CNRS, 2002. 
Orr, J., Najjar, R., Sabine, C., and Joos, F.: Abiotic HOWTO, Tech. rep., LSCE/CEA Saclay, Gif-sur-Yvette, France, 2000.

Orsi, A. H., Whitworth, T., and Nowlin, W. D.: On the meridional extent and fronts of the Antarctic Circumpolar Current, DeepSea Res. I, 42, 641-673, 1995.

Pacanowski, R. C.: MOM 2 Documentation, User's Guide and Reference Manual, Technical report, GFDL Ocean Group, NOAA, GFDL, Princeton, New Jersey, 1995.

Peltier, R.: Global Glacial Isostacy and the Surface of the Ice-Age Earth: The ICE-5G (VM2) Model and GRACE, Earth Planet. Sci., 32, 111-149, 2004.

Reimer, P. J. and Reimer, R. W.: A marine reservoir correction database and on-line interface, Radiocarbon, 43, 461-463, 2001.

Reimer, P. J., Baillie, M. G. L., Bard, E., Bayliss, A., Beck, J. W., Bertrand, C. J. H., Blackwell, P. G., Buck, C. E., Burr, G. S., Cutler, K. B., Damon, P. D., Edwards, R. L., Fairbanks, R. G., Friedrich, M., Guilderson, T. P., Hogg, A. G., Hughen, K. A., Kromer, B., McCormac, G., Manning, S., Ramsey, C. B., Reimer, R. W., Remmele, S., Southon, J. R., Stuiver, M., Talamo, S., Taylor, F. W., Plicht, J. v. d., and Weyhenmeyer, C. E.: INTCAL04 Terrestrial Radiocarbon Age Calibration, 0-26 cal kyr BP, Radiocarbon, 46, 1029-1058, 2004.

Sarnthein, M., Stattegger, K., Dreger, D., Erlenkeuser, H., Grootes, P., Haupt, B. J., Jung, S., Kiefer, T., Kuhnt, W., Pflaumann, U., Schäfer-Neth, C., Schulz, H., Schulz, M., Seidov, D., Simstich, J., Kreveld, S. v., Vogelsang, E., Völker, A., and Weinelt, M.: Fundamental Modes and Abrupt Changes in North Atlantic Circulation and Climate over the last $60 \mathrm{ky}$ - Concepts, Reconstruction and Numerical Modeling, in: The Northern North Atlantic, edited by: Schäfer, P., Ritzrau, W., Schlüter, M., and Thiede, J., Springer Verlag, New York, 365-410, 2001.

Sarnthein, M., Grootes, P. M., Kennett, J. P., and M.-J., N.: ${ }^{14} \mathrm{C}$ Reservoir Ages Show Deglacial Changes in Ocean Currents, in: Ocean Circulation: Mechanisms and Impacts, Geophysical Monograph Series 173, edited by: Schmittner, A., Chiang, J., and Hemming, S., American Geophysical Union, Washington, DC, 175-197, 2007.

Schiebel, R. and Hemleben, C.: Modern planktic foraminifera, Paläontologische Zeitschrift, 79, 135-148, 2005.

Schimmelmann, A., Lange, C. B., Roark, B., and Ingram, L.: Resources for paleoceanographic and paleoclimatic analysis: A 6,700-year stratigraphy and regional radiocarbon reservoir-age $(\Delta \mathrm{R})$ record based on varve counting and ${ }^{14} \mathrm{C}$-AMS dating for the Santa Barbara Basin, offshore Carlifornia, U.S.A., J. Sediment. Res., 76, 74-80, 2006.

Schmittner, A., Meissner, K. J., Eby, M., and Weaver, A. J.: Forcing of the deep ocean circulation in simulations of the Last Glacial Maximum, Paleoceanography, 17, 26-35, 2002.

Shi, N., Schneider, R., Beuga, H.-J., and Dupont, L. M.: Southeast trade wind variations during the last $135 \mathrm{kyr}$ : evidence from pollen spectra in eastern South Atlantic sediments, Earth Planet. Sci. Lett., 187, 311-321, 2001.

Siani, G., Paterne, M., Michel, E., Sulpizio, R., Sbrana, A., Arnold, M., and Hadded, G.: Mediterranean Sea Surface Radiocarbon Reservoir Age Changes Since the Last Glacial Maximum, Science, 294, 1917-1920, 2001.

Siegenthaler, U., Heimann, M., and Oeschger, H.: ${ }^{14} \mathrm{C}$ Variations caused by changes in the global carbon cycle, Radiocarbon, 22, 177-191, 1980.
Sikes, E. L., Samson, C. R., Guilderson, T, P., and Howard, W. R.: Old radiocarbon ages in the southwest Pacific Ocean during the last glacial period and deglaciation, Nature, 405, 555-559, 2000.

Simstich, J., Sarnthein, M., and Erlenkeuser, H.: Paired $\delta^{18} \mathrm{O}$ signals of Neogloboquadrina pachyderma (s) and Turborotalita quinqueloba show thermal stratifcation structure in Nordic Seas, Mar. Micropaleontol., 48, 107-125, 2003.

Southon, J. R., Nelson, D. E., and Vogel, J. S.: A record of past ocean-atmosphere radiocarbon difference from the northeast $\mathrm{Pa}$ cific, Paleoceanography, 5, 197-206, 1990.

Stuiver, M. and Braziunas, T. F.: Modeling atmospheric ${ }^{14} \mathrm{C}$ influences and ${ }^{14} \mathrm{C}$ ages of marine samples to $10,000 \mathrm{BC}$, Radiocarbon, 35, 137-189, 1993.

Stuut, J.-B. W., Prins, M. A., Schneider, R. R., Weltje, G. J., Jansen, J. H. F., and Postma, G.: A 300-kyr record of aridity and wind strength in southwestern Africa: inferences from grain-size distributions of sediments on Walvis Ridge, SE Atlantic, Mar. Geol., 180, 221-233, 2002.

Sweeney, C., Gloor, E., Jacobson, A. R., Key, R. M., McKinley, G., Sarmiento, J. L., and Wanninkhof, R.: Constraining global airsea gas exchange for $\mathrm{CO}_{2}$ with recent bomb ${ }^{14} \mathrm{C}$ measurements, Global Biogeochem. Cy., 21, 1-10, 2007.

Talley, L. D., Reid, J. L., and Robbins, P. E.: Data-based meridional overturning streamfunctions for the global ocean, J. Climate, 16, 3213-3226, 2003.

Toggweiler, J., Dixon, K., and Bryan, K.: Simulations of Radiocarbon in a Coarse-Resolution World Ocean Model - 1. Steady State Prebomb Distribution, J. Geophys. Res., C94, 8217-8242, 1989.

Valet, J.-P., Meynadier, L., and Guyodo, Y.: Geomagnetic dipole strength and reversal rate over the past two million years, Nature, 435, 802-805, 2005.

van Kreveld, S., Sarnthein, M., Erlenkeuser, H., Grootes, P., Jung, S., Nadeau, M. J., Pflaumann, U., and Voelker, A.: Potential links between surging ice sheets, circulation changes, and the Dansgaard-Oeschger cycles in the Irminger Sea, Paleoceanography, 15, 425-442, 2000.

Voelker, A. H. L., Sarnthein, M., Grootes, P. M., Erlenkeuser, H., Laj, C., Mazaud, A., and Nadeau, M.-J.: Correlation of marine ${ }^{14} \mathrm{C}$ ages from the Nordic Seas with the GISP2 isotope record: Implications for ${ }^{14} \mathrm{C}$ calibration beyond $25 \mathrm{ka} \mathrm{BP}$, Radiocarbon, 40, 517-534, 1998.

Voelker, A. H. L., Grootes, P. M., Nadeau, M.-J., and Sarnthein, M.: Radiocarbon levels in the Iceland Sea from $25-53 \mathrm{kyr}$ and their link to the Earth magnetic field intensity, Radiocarbon, 42, 437-452, 2000.

Waelbroeck, C., Duplessy, J.-C., Michel, E., Labeyrie, L., Paillard, D., and Dupart, J.: The timing of the last deglaciation in North Atlantic climate records, Nature, 412, 724-727, 2001.

Weaver, A. J., Eby, M., Wiebe, E. C., Bitz, C. M., Duffy, P. B., Ewen, T. L., Fanning, A. F., Holland, M. M., MacFadyen, A., Matthews, H. D., Meissner, K. J., Saenko, O., Schmittner, A., Wang, H., and Yoshimori, M.: The UVic Earth System Climate Model: Model Description, Climatology, and Applications to Past, Present and Future Climates, Atmos.-Ocean, 39, 361-428, 2001.

Williams, T. and Kelley, C.: gnuplot - An Interactive Plotting Program, 2007. 